INTERNATIONAL JOURNAL OF RESEARCHES IN BIOSCIENCES, AGRICULTURE AND TECHNOLOGY (c) VISHWASHANTI MULTIPURPOSE SOCIETY (Global Peace Multipurpose Socie ty) R. No. MH-659/13(N) www.vmsindia.org

\title{
SPECIES RICHNESS AND DIVERSITY OF ANTS IN NAGPUR CITY (MS), INDIA
}

\author{
Seema. G. Kadu \\ De partment of Zoology, \\ S.S.E.S. Amt's Science College, Nagpur \\ seema.kadu@sscn.in
}

\begin{abstract}
:
Ants deserve a special place among the arthropod fauna to the study of ecology, including behavior, species richness, social habits and high densities. Ants are only constitute the largest chunk of the insects belonging to the endopte rygote group. Up to this study 35 species of ants in 22 gene ra from 6 subfamilies were identified only. The se ant spe cies belong to five subfamily, Componotinae, Formicinae, Myrmicinae, Ponerinae, Dolichode rinae and Pseudomyrmicinae. In Nagpur (MS) re gion most of the tropical, warm, and temperate genera of ants belong to the subfamilies Crematogaster, Ponerinae and Componotinae are described. Ants are the dominant and successful component of ecosystem, as well as good indicators of ecosystem. The study of species richness and relative abundance of ant population and its cosmopolitan distribution is very important as they are considerable economic importance. The most frequently obse rved genus of Ants in Nagpur District are Camponotus, Solenopsis and Crematogaster followe d by the genera Pheidole Myrmica and Dorylus.
\end{abstract}

Keyw ords: Endopte ryote, Vidarbha, Ponerinae, Componotinae.

\section{Introduction:}

Ants are the important invertebrates play significant role in the delivery of ecosystem also participated actively in the interactions that develop quality of soil. Ants are important in below ground processes through the alteration of the physical and chemical environment and through their effects on plants, microorganisms, and other soil organisms. Many ant species gives an indication of ecosystem health and functioning while some species are purists reliant on undisturbed ecosystems, others are weeds or even invasive. Ants occupy a great variety of habitats, with about 12,000 known species worldwide. Their biomass exceeds that of all vertebrates combined. Their social organization is orchestrated by intricate che mical communication (Johnson et al., 2013). Their abundance and varied ecological roles make them influential in agricultural ecosystems around the world (Gadagkar et al.,1993). The role of ants in ecosystems is discussed, mainly from the perspective of the effects of ground-dwelling ants on soil processes and function, emphasizing their role as ecosystem engineers (Folgarait, 1998). Improved understanding of ants, how to identify them, where they live, what they do is the refore a vital task in sustainably developing world. Perhaps the study of diversity, relative abundance and species richness of ants in Nagpur region of Maharashtra state shows some ecologically important species. Due to rapid urbanization amid growing concern about biodiversity loss of some ant species and communities are at risk of disappearing even appearing on the IUCN Red List, while some invasive contribute to the extinction of other creatures (Holldobler and
Wils on, 1990; Bharti and Alpert, 2007).

The present study work carried out in District Nagpur which is the metropolitan city in the state of Maharashtra, India located at $21^{\circ} 56^{\prime} \mathrm{N}$ $76^{\circ} 45^{\prime} \mathrm{E}$. In Maharashtra state ant fauna, represent the diverse group of species, including ten known subfamilies like; Aenictinae, Amblyoponinae, Cerapachyinae, Dolichoderinae, Dorylinae, Ectatomminae, Formicinae, Leptanillinae, Myrmicinae, Ponerinae, Proceratiinae and Pseudomyrmecina (Nagaria and Pawar, 2014). All these species shows different variety of habitats such as leaf litter, trees, soil and dead logs, while tramp species prefer human-modified habitats.

\section{Material and Methods:}

Ants, in general, are very easy to sample. Baiting techniques, pitfall traps, aspirators, litte $r$ sifting, Berlese-Tullgren or Winkler funnels for litter or soil core samples, and hand collections with forceps or nets are among the most common methods to sample ground foraging ants. All these methods are easy to use, cheap, and not incredibly time consuming. It should not take more than three days of fulltime work using several methods to obtain a complete list of the ant fauna from 1 ha of soil (Holldobler and Wilson, 1990, Folgarait, 1998). The addition of ground baiting and Winkler analysis for litter samples increased the efficiency of richness estimations by $20 \pm 30 \%$ whe n compared to the combined use of pitfalls, hand collections, and sweep net (Majer, 1996).

\section{Collection of Ant Species-}

The ant samples were collected from diffe rent sites of Nagpur city to study the dive rse 
group of different species. The samples were collected randomly from the selected area using blunt forceps and collected in wide mouthed jars with killing agent (70\% alcohol). The sampling and study of diversity of ants is a continuous survey method.

\section{Identification of Ant-}

The ants were identified up to the genus level using the taxonomic keys by B. Bolton (Holldobler and Wilson, 1990) for the Oriental region. Further each genus was classified into recognizable taxonomic units (RTU's) based on morphological differences. For convenience, these RTU's are referred to as species. The collected ants were identified by using Stereo Microscope based on identification key (Mathew R.N. and Tiwari, 2000; Bolton B, 1994, 2003).

\section{Result and Discussion:}

In the present study of species richness and ant diversity 35 ant species belonging to 22 genera and 6 subfamilies were recorded (Table 1). Comparison of ant species distribution between the different study sites revealed that ant species richness was highest at garden areas than the industrial a reas. Relatively high species rich genera are Camponotus and Crematogaster followed by the Pheidole and Solenopsis was recorded at all the study sites with dense vegetation. On the other hand, monoculture plantations showed fewer number of ant species. Similarly, ant species richness was low in around urban houses.

Also it was revealed that the soil ants are belong to different trophic levels (leaf-cutter and harvester ants as primary consumers; predators and melivores as secondary consumers), probably can be classified as ecosystem engineers. This is because of their basically species richness and similar effects on soil structure and processes which directly or indirectly affect the flow of energy and material in ecosystems as well as the habitats of other species.

Tropical habitats have a rich store of ant diversity. Unfortunately, data on the ants of both natural and manmade habitats are poor, especially for the Indian region (Gadagkar et al. 1993). The prime objectives of this study are to prepare a partial checklist of ants of ants in Nagpur city to compare ant species richness between selected study sites. In the present study, Twe nty three ant species were collected fro $m$ the diffe re $n t$ region at random (Table-1). The species diversity indices in 22 ge nera representing six subfamilies namely were slightly different showing vegetative, industrial habitats. The diverse ant species belonging the subfamilies are Formicinae, Camponotinae, Myrmicinae, Ponerinae and Dolichoderinae we re highest in general habitat following by Pseudomyrmicinae and Dorylinae. The subfamily Formicinae, having seven species is widely distributed in all geographic territory. This data correlate with the present studies of different workers (Chavan and Pawar, 2011).The genus Camponotus were record of three species in all the study area. The Carpenter ants are the polymorphic important insect because of their "Nesting Behaviors" (Kadu et al, 2010) in the tree trunks, agriculture soil increasing porosity and nutritive value. Some of the ants which are reported as an important urban pest related to with human communities are Pharaoh ant Monomorium pharaonis and red ant Solenopsis nana are found in the study in the most of locality. These are omnivores feeding on wide varie ties of food. Usually, they are outdoors and nesting in the soil at the base of trees, rotten wood, decayed tree parts or beneath leaf litter. These ants raid other ant colonies capture their brood and workers, tame and use them for their own household chores. Many other interesting behaviors are exhibited by ants e.g. some like Solenopsis and some harvester ants show jumping behavior for prey captured, some show aggressive postures etc. Another form of behavior which is elucidated by many ant species like Formica (native to Himalaya and all parts of the world) is known as slavery.

It is really unfortunate in present scenario that much emphasis has been laid on those natural resources which are of direct importance to humans and to look for alternative resources in the wake of exhaustion of natural resources. Ants provide many services free of cost which ensure the survival of our race. They are the major soil turners, channels of energy, pollinators, scavengers, biological control agents and to sum up the ants are important component of food chain. More recently they are being used as indicator organisms which provide us cues regarding our deteriorating ecosystems. We conclude that while ant species richness generally increases with increase in vegetation and declines with increase industrialisation and urbanisation in cities. Present study reveals the importance of diverse group of ants as they are an important component of our food chain as important to generate resources and cleardebris from earth. 
Table-1: Partial Checklist of ants specie s in Nagpur region.

\begin{tabular}{|c|c|c|c|}
\hline S.No. & Sub-Family & Genus & species \\
\hline \multirow[t]{3}{*}{1.} & \multirow{3}{*}{ Dolichoderinae } & Iridomyrmex & I. anceps (Roger, 1863) \\
\hline & & Dolichoderus & D. sundari (Mathew and Tiwari, 2000) \\
\hline & & Tapinoma & T. indicum (Forel,1895) \\
\hline 2. & Dorylinae & Dorylus & D. labiatus (Shuckard, 1840) \\
\hline \multirow[t]{3}{*}{3.} & \multirow[t]{3}{*}{ Formicinae } & Formica & $\begin{array}{l}\text { F. rufa } \\
\text { C. compressus (Fabricus, 1787) } \\
\text { C.wasmanni (Emery, 1893) } \\
\text { C. paria (Emery, 1889) } \\
\text { C. gigas (Latre ille, 1802) } \\
\text { C. maculatusbasalis (Smith, 1878) }\end{array}$ \\
\hline & & Oecophylla & $\begin{array}{l}\text { O.smaragdina (Fabricius, 1775) } \\
\text { O. longinoda(L atre ille, 1802) }\end{array}$ \\
\hline & & $\begin{array}{l}\text { Paratrechina } \\
\text { Polyrchis }\end{array}$ & $\begin{array}{l}\text { P. longicornis (Latreille,1802) } \\
\text { P. rastella (Latre ille, 1802) }\end{array}$ \\
\hline \multirow[t]{13}{*}{4.} & \multirow{13}{*}{ Myrmicinae } & Triglyphoth trix & T. obese (Andre, 1887) \\
\hline & & Aphaenogaster & A. rotheyi (Forel,1902) \\
\hline & & Dilobocondyla & \\
\hline & & Monomorüm & $\begin{array}{l}\text { M. pharohnis (Forel 1902) } \\
\text { M. glabrum (Atdr, 1883) } \\
\text { M. indicum (Forel, 1902) } \\
\text { M. indica(Weber, 1950) }\end{array}$ \\
\hline & & Myrmicaria & M. brunnea(Saunders 1841) \\
\hline & & \multirow{4}{*}{ Crematogaster } & C. diffusa(Jordon, 1851) \\
\hline & & & C. abdominalis (Motschoulsky 1863) \\
\hline & & & C. rogenhoferi (Mayr, 1878) \\
\hline & & & C. cerasi (Mayr, 1878) \\
\hline & & Solenopsis & $\begin{array}{l}\text { S. molesta } \\
\text { S. invicta }\end{array}$ \\
\hline & & Tetramorium & T. guineese (Fabricus, 1793) \\
\hline & & Pheidole & P. megacephala (Fabricius, 1793) \\
\hline & & Pheidologeton & $\begin{array}{l}\text { P. diversus (Jerdon, 1851) } \\
\text { P.flavens } \\
\text { P.affinis }\end{array}$ \\
\hline \multirow[t]{2}{*}{5.} & \multirow{2}{*}{ Ponerinae } & Leptogenys & L. dentilobis (Forel,1895) \\
\hline & & Pachycondyla & P. rufipes \\
\hline 6. & Pseudomyrmicinae & Tetraponera & T. nigra (Jerden)) \\
\hline
\end{tabular}

\section{References:}

Aravind Chavhan and S. S. Pawar (2011). Distribution and Diversity of Ant Species (Hymenoptera: Formicidae) in and Around Amravati City of Maharashtra, India.World Journal of Zoology 6 (4) : 395-400.

Bolton B. (2003). Synopsis and classification of Zoological Survey of India Fauna of Meghalaya, Formicidae. Memoirs of the American, Entomological 7: 251-409. Institute, 71: 1-370.

Bolton, B., (1994). Identification Guide to the Ant Ge nera of World. Cambridge: Harvard University "Newly discove re d sis te r lineage sheds light on Press.

Bharti, H. and G.D. Alpert, (2007). Ants of India.Downloaded from ww.antdiversity.com/ 26 Dece mber 2007.

Folgarait, (1998). Ant dive rsity and its relation ship to ecosystem functioning: a review. J. Biodiv. And Conserv. : 7: 1221-1244.
Gadagkar, R., P. Nair, K. Chandrashekhar and D.M. Bhat, (1993). Ant species richness in some selected localities in Western Ghats, India. Hexapoda, 5: 7094.

Holldobler, B. and E.O. Wilson, (1990). The Ants. Springer-Verlag.

Kadu S. G., Barsagade D.D. and Tembhare D.B. (2010). Effect of plant extract on carpenter ant Camponoyus compressus,

Sunil Kumar, M., K.T. Shrihari, P. Nair, T. Varghese and $\mathbf{R}$. Gadagkar, (1997). Ant Species Richness selected localities of Bangalore. 3(1): 3-5.

Sunil Kumar M, Srihari K.T, Padmini Nair, Thresiamma Varghese and Raghavendra Gadagkar (1997). Ant Species Richness at selected localities of Bangalore. Insect Environment, Vol.3, (1), AprilJune 